解 説

\title{
人獣共通感染症（動物由来感染症）の情報面における獣医系の役割と期待
}

砂川富正*

国立感染症研究所感染症疫学センター

\section{The Veterinarians' Role and Expectation for the Surveillance of Zoonosis in Japan}

\author{
Tomimasa SUNAGAWA*
}

Infectious Disease Surveillance Center, National Institute of Infectious Diseases

\section{Summary}

One of the important measures to enhance the preparation and response against zoonosis is to strengthen the surveillance system in the fields of both medicine and veterinary medicine. The importance of zoonosis occurring in pet animal has recently been emphasized. More efficient and active response to zoonotic diseases fulfills the philosophy of "One Health" which is the concept for all the relevant groups, human, animal and environment health, to work together.

\section{はじめに}

人と動物が同じ病原体に感染して発症する疾患は動物由 来感染症，または人獣共通感染症と呼ばれる。そのほとん どは本来動物が保有する病原体が原因となるが1)，人から 動物に感染が及んだ例としても，2009 年に新型インフル エンザであった $\mathrm{A}(\mathrm{H} 1 \mathrm{~N} 1)$ pdm09（現在の季節性インフル エンザの一つ）によるブタの感染などが知られる2)。人に 感染しうる病原体として，これまで千数百種類の寄生虫, 原虫, 真菌, 細菌, ウイルスなどが報告され，うち重要な 動物由来感染症の原因となるものは世界的に 200 300 種 類，現在わが国には 100 種類近くが存在するとされる ${ }^{1)} 。$

国立感染症研究所感染症疫学センターの主たる業務の一 つは,「感染症の予防及び感染症の患者に対する医療に関 する法律 (感染症法) 」) による医師及び獣医師に義務付け られた感染症及び対象動物からの届出について, 自治体が 収集・確認した情報を，国の機関としての立場での総合・ 分析・還元を行うことである。これら一連の情報の流れを，

\section{連絡先 : 砂川富正*}

国立感染症研究所感染症疫学センター 干162-8640 東京都新宿区戸山 1-23-1 Tel : 03-5285-1111（代）; Fax : 03-5285-1177 E-mail : sunatomi@niid.go.jp
主に公衆衛生の立場からの「感染症サーベイランス」と称 する。感染症法に獣医師の届出対象疾患が存在することに ついては，行政関連の獣医師であれば周知であると思われ るが，開業獣医師においては，十分に周知されていない状 況を聞くことがある（私信）。動物由来感染症のうち, 今後, 人との関係がより緊密になっている愛玩動物に由来する疾 患（愛玩動物由来感染症）が増加する可能性が指摘されて もおり，本稿においては，飼育愛玩動物を多く取り扱う可 能性が高い開業獣医師を対象として考慮した。「感染症サー ベイランス」について，感染症法に基づいたサーベイラン スのシステムや感染症疫学センターとの関わり, 獣医師が 届け出を行う感染症及び対象動物とその推移について解説 し，感染症法における獸医師による届出対象疾患ではない ものの，飼育愛玩動物であるイヌにおいても疾患が発生し うるレプトスピラ症に関する分析，感染症サーベイランス において獣医師に期待される役割や今後の展望などについ て述べてみたい。

\section{感染症法に基づいたサーベイランスの システムとは}

まず，サーベイランス（surveillance）とは，疾病の予防 と管理を目的として, 疾病の発生状況やその推移などの デー夕を継続的，系統的に収集・分析・解釈・評価し，そ 
の結果を迅速あるいは定期的に, 対策部門へ情報提供を行 うものである ${ }^{4)}$ 。情報が対策に結び付くことが重要であり， (1)データの収集, (2)デー夕の報告, (3)デー夕の整理·分析· 解粕，(4)情報の還元，(5)予防と管理（対策）の実行，(6) らに新たなデータの収集（（11へ戻る）へと，サーベイラ ンスはループを描いて稼働する。これらは, いずれも継続 的かつ系統的に行われることが重要である。デー夕の対象 は個人（個別の動物）ではなく集団であることから，疾病 サーベイランスあるいは公衆衛生サーベイランス（Public Health Surveillance) と呼ばれることもある。

教科書的に，信頼のおける均一のデー夕を収集するため には, (1)デー夕提供者の動機づけ, (2)容易な収集方法, (3) 収集するデー夕の明確な定義, (4)適時性, (5)完全性,の 5 点に留意する必要がある, とされる。わが国で最も広く実 施されているサーベイランスは, 厚生労働省（開始当初は 厚生省）が1981（昭和 56）年より実施している「感染症 発生動向調查」である。感染症サーベイランスの目的は, 一般的には 1）流行疾患の動向監視，2）集団発生（アウ トブレイク）の探知と現状評価・リスク評価，3）感染症 対策の評価（刘策による変化の監視，対策の進渉の監視）, 4）今後の動向・流行の予測, などである。1）や2）につ いて，アウトブレイクを早期に探知することは，（動物を 含む）疾病の健康被害が甚大化する前の早期の介入や対策 の実施を行うことが可能となることを意味しており，その 結果, さらなる患者 (感染動物) の発生を防止することが 出来るかもしれず，サーベイランスにはそのような目的と 期待がかる。

わが国における感染症発生動向調査事業（以下, 発生動 向調査事業) は, 1981 (昭和 56) 年から開始され, 1987 (昭 和 62 年) 1 月からはコンピューターを用いたオンライン システムとして拡大されて運用されてきた。そして, 1999 (平成 11) 年 4 月に感染症法 ${ }^{3}$ が施行されたことに伴い, 感染症法に基づく施策として位置づけられている。発生動 向調査事業の中で, 国内の感染症に関する情報の収集抒よ び公表, 発生状況掞よび動向の把握は感染症法第 12 条〜 第 16 条に基づいて実施されている。発生動向調查事業で は, 患者 (感染動物) 情報は, 対象疾患を診断した医師・ 獣医師（定点把握疾患については指定届出機関の管理者） から保健所へ届出のあった感染症に関する情報について, 届出を要する感染症の種類と届出基準については, 感染症 法, 感染症法施行規則, および通知「感染症法第 12 条第 1 項及び第 14 条第 2 項に基づく届出の基準等について」(平 成 18 年 3 月 8 日 健感発 0308001 号), 感染症サーベイラ ンスシステム〔National Epidemiological Surveillance of Infectious Disease (NESID)]により, 都道府県を通じて, 厚生 労働省に報告される (図 1 $)^{5)}$ 。その具体的な流れの中で重
要なことは，まず診断医から届出られた内容を保健所が確 認の上でNESID の入力登録を行っている点である。自 治体内の地方感染症情報センターでは, 管轄地域の登録 デー夕を精查して確認し, さらに, 国立感染症研究所内の 中央感染症情報センター（感染症疫学センター）は, 全国 の登録デー夕を精查した上で集計を行っている。これらの 流れの中で, 集計としてのデータの精查と, 対応すべき事 象の拾い上げが幾重のバリアを通して行われるようになっ ており，わが国の感染症サーベイランスシステムにおける 大きな特徵となっている。

ちなみに医師及び獣医師がこの届出を急る場合には，同 法第七十七条において「五十万円以下の罰金に処する。」) と規定されていることを知らない医師・獣医師は多い。

\section{獣医師が届け出を行う感染症及び 対象動物とその推移}

感染症法により獣医師の届出が義務付けられている対象 疾患及び動物の変遷については, 動物由来感染症対策強化 が重点の一つとして2003年 10 月の感染症法改正が行われ, それにともない,「エボラ出血熱のサル」,「マールブルグ 病のサル」,「ペストのプレーリードッグ」,「重症急性呼吸 器症候群 (SARS) のイタチアナグマ・タヌキ・ハクビシン」 から,「細菌性赤㾥のサル」,「ウエストナイル熱の鳥類」, 「エキノコックス症の犬」を加えた 7 疾患となった (2004 年 10 月 1 日施行)。その後,「インフルエンザ (H5N1) の 鳥類」が届出対象となり（2006 年 6 月 12 日施行，ただし 2008 年 5 月 12 日からは 2 類感染症の「鳥インフルエンザ (H5N1）の鳥類」として報告), さらに 2007 年 4 月の感染 症法と結核予防法との統合により「結核のサル」が追加さ れ（2007 年 4 月 1 日施行），併せて届出基準も制定された。 これを踏まえ, これらの疾患については, 感染症法第 13 条により, “感染または感染が疑われる対象動物を診断し た獣医師”あるいは“感染または感染が疑われる対象動物 を認めた動物の所有者”による届出が義務付けられること となった。また, 2013 年 5 月 6 日より, 鳥インフルエン ザ（H5N1 又は H7N9）に変更された。MERSは, 2015 年 1 月 21 日から感染症法に打いて, 二類感染症として施行 されている。獣医師は, PCR 法あるいはウイルス分離に よる病原体（遺伝子を含む）の検出により, ヒトコブラク ダ又はその死体について中東呼吸器症候群の病原体診断を した場合，あるいは疑いがある（あった）と診断・検案し た場合は感染症法第 13 条第 1 項の規定による届出を行わ なければならない。

感染症および対象動物 ${ }^{6}$ 及び現時点までに確定している 2014 年までの推移を参考文献の記述 ${ }^{7}$ に従って, 表に示す ${ }^{8)}$ 。 鳥インフルエンザについては, 同一養䳕場で複数発生して 


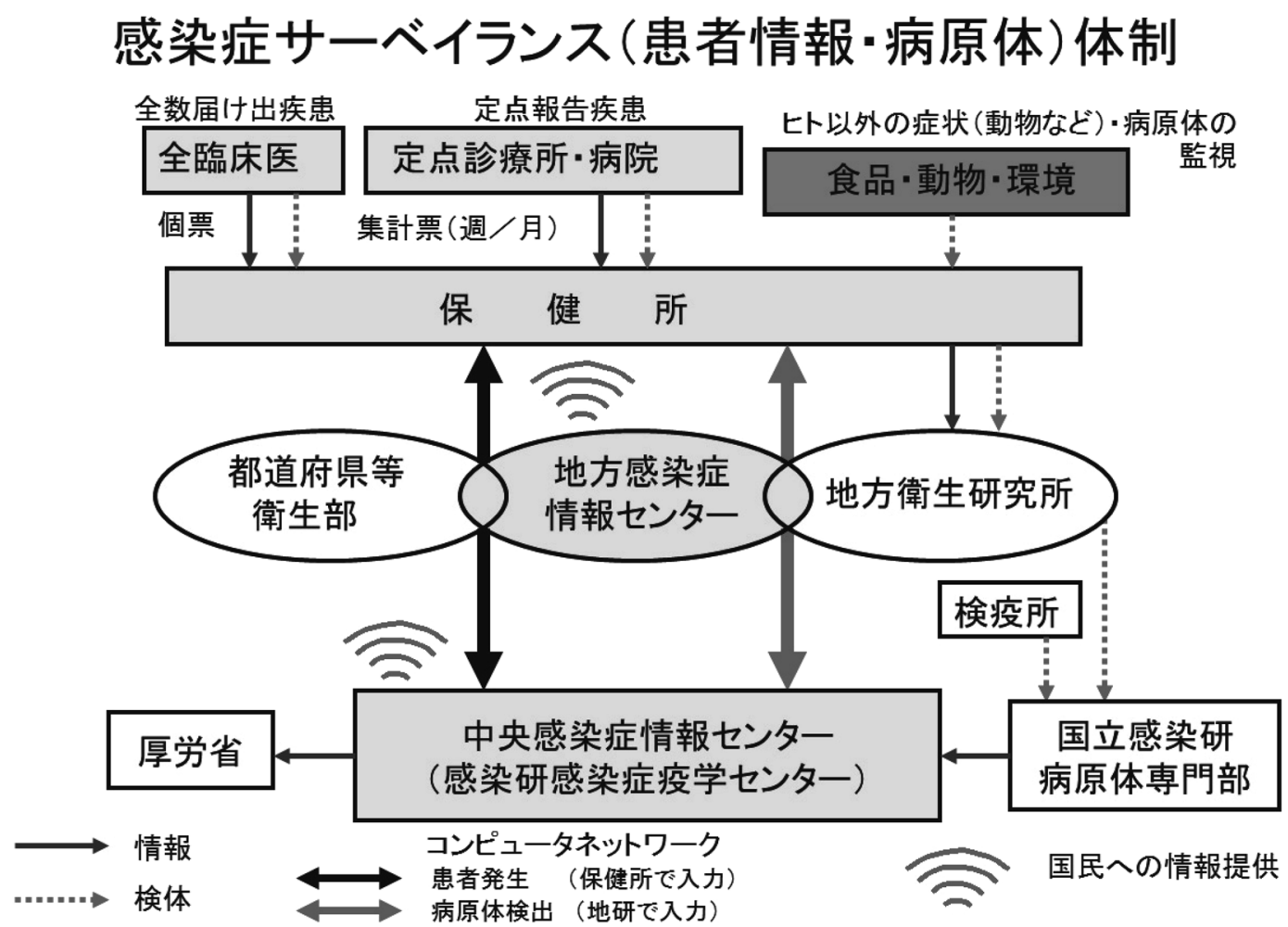

図 1 感染症法に基づくサーベイランス体制の概要

表＼cjkstart感染症法に基づき獣医師が届出を行う感染症・対象動物及び報告状況（2004-2014 年）

\begin{tabular}{|c|c|c|c|c|c|c|c|c|c|c|c|c|c|c|}
\hline \multirow{2}{*}{$\begin{array}{l}\text { 感染症法 } \\
\text { による類 }\end{array}$} & \multirow{2}{*}{ 疾患名 } & \multirow{2}{*}{ 対象動物 } & \multicolumn{12}{|c|}{ 報告数(西暦) } \\
\hline & & & 2004 & 2005 & 2006 & 2007 & 2008 & 2009 & 2010 & 2011 & 2012 & 2013 & 2014 & 計 \\
\hline \multirow{3}{*}{ 1類 } & エボラ出血熱 & サル & 0 & 0 & 0 & 0 & 0 & 0 & 0 & 0 & 0 & 0 & 0 & 0 \\
\hline & マールブルグ病 & サル & 0 & 0 & 0 & 0 & 0 & 0 & 0 & 0 & 0 & 0 & 0 & 0 \\
\hline & ํ자 & プレーリードッグ & 0 & 0 & 0 & 0 & 0 & 0 & 0 & 0 & 0 & 0 & 0 & $\underline{0}$ \\
\hline \multirow{4}{*}{ 2類 } & $\begin{array}{l}\text { 重症急性呼吸器症候群: SARS } \\
\text { (SARSコロナウイルスによに } \\
\text { 限る) }\end{array}$ & $\begin{array}{l}\text { イタチアナグマ } \\
\text { タヌキ } \\
\text { ハクビシン }\end{array}$ & 0 & 0 & 0 & 0 & 0 & 0 & 0 & 0 & 0 & 0 & 0 & 0 \\
\hline & 鳥インフルエンザ(H5N1又はH7N9) & 鳥類 & - & $E$ & 0 & 5 & 5 & 0 & 9 & 72 & 0 & 0 & 0 & 91 \\
\hline & 結核 & サル & E & E & - & 0 & 0 & 0 & 0 & 0 & 0 & 0 & 9 & 0 \\
\hline & 中東呼吸器症候群 & ヒトコブラクダ & - & $E$ & - & - & E- & I- & I- & $E$ & & $z$ & 0 & $\underline{0}$ \\
\hline 3類 & 細菌性赤痢 & サル & 0 & 45 & 45 & 51 & 29 & 34 & 59 & 37 & 2 & 5 & 6 & 313 \\
\hline \multirow{2}{*}{ 4類 } & ウエストナイル熱 & 鳥類 & 0 & 0 & 0 & 0 & 0 & 0 & 0 & 0 & 0 & 0 & 0 & 0 \\
\hline & エキノコックス症 & 仅 & 0 & 5 & 2 & 1 & 1 & 2 & 1 & 0 & 0 & 0 & 1 & 13 \\
\hline
\end{tabular}

参考文献 7）8）の情報をベースに編集.

結核のサルの報告数は 2007 年 4 月 1 日からの数值である。

鳥インフルエンザ（H5N1 又は H7N9）の鳥類の報告数は 2006 年 6 月 12 日からの数值である。

2008 年 5 月 12 日より，インフルエンザ（H5N1） から鳥インフルエンザ（H5N1）に名称を変更し，2013 年 5 月

6日より，鳥インフルエンザ（H5N1 又はH7N9）に変更した。

中東呼吸器症候群の報告数は 2014 年 7 月 26 日からの数值である。

いる場合に1例としてカウントされている例がある。また， 2004 年から 2014 年までの累計で最も報告が多かったのは 細菌性赤㾥（対象動物：サル）であり，全体の 3 分の 2 ほ どまである 2009 年時点で大多数を占めていたのは,
Shigella flexneri であったとの報告がある7”。野生で捕獲直 後の個体では赤痢菌は分離されず，飼育環境下の粪便で污 染された飼料や水, 器具を介して経口的に感染するとのこ とで，国内でもペットのサルから感染した事例などもある 
(報告数)

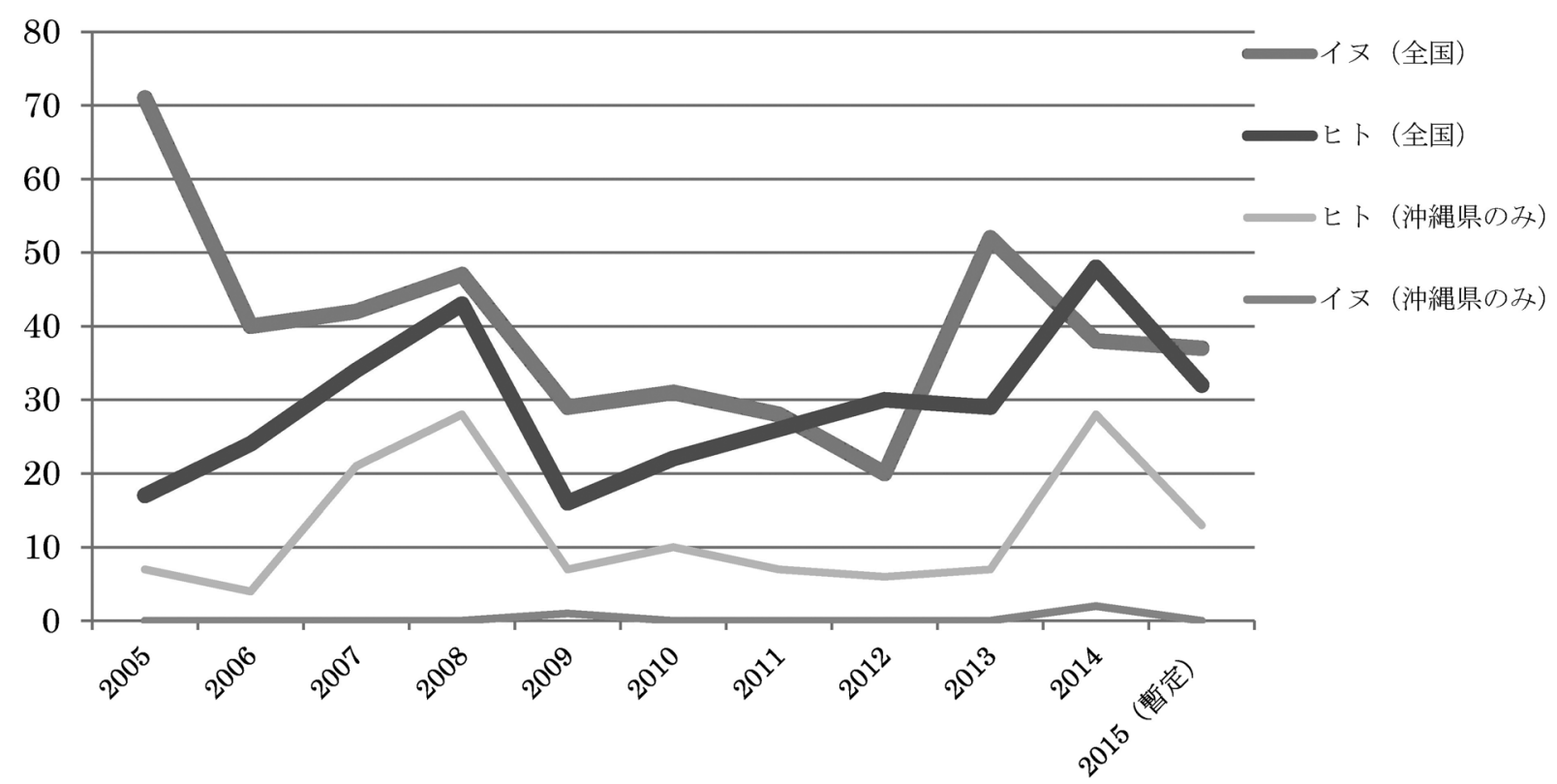

図 2 ヒト及びイヌのレプトスピラ症報告数の推移（2005２015 年）

ヒト報告数については（全国）感染症発生動向調査（参考文献 16）及び沖縄県記者発表（参考文献 17）より。 イヌ報告数（全国及び沖縄県）については監視伝染病発生年報（参考文献 13）より。

ことから, 特にペットとしての飼育にはなじまないことが 言及されている9)。

\section{レプトスピラ症に関する分析}

レプトスピラ症は病原性レプトスピラ (Leptospira interrogans など）による, 多様な症状を示す急性の人獣共通の 感染症である ${ }^{10)}$ 。病原性レプトスピラを腎臓に保有してい るネズミ, イヌ, ウシ, ウマ, ブタ, マングースなどの尿 で污染された下水や河川, 泥などにより, ヒトは経皮的に, 時には污染された飲食物の摂取により経口的に感染する。 ヒトにおいては, 高熱, 黄疸, 筋肉痛 - 関節痛 - 結膜充血 などを主症状とし, 重症になると出血, 腎障害などの症状 が現れ, 死に至ることもある。ヒト患者では, 感染症法上 第 4 類感染症として, 全ての患者の報告が必須である ${ }^{10)}$ 。 2007 年 1 月から 2016 年 4 月末まで届出られた同症の国内 全患者 (258 例) のうち, 推定感染地としては沖縄県が 55\%（142 例）と最も多かった ${ }^{11)}$ 。また, 家畜伝染病予防 法においては, イヌのレプトスピラ症は病性も強く, イヌ それ自体だけでなく, ウシ, ブタ等の基幹家畜へ感染する おそれもある伝染性疾病であるため ${ }^{12)}$, 一般飼主を含めた 届出伝染病に指定されている。2007 年 1 月から 2015 年 12 月までのイヌのレプトスピラ症の報告数は全国で計 324 例 であった。うち, 沖縄県の占める割合は $0.9 \%$ (3 例) であっ
た ${ }^{13)}$ 。

2009 年夏に宮崎県においてレプトスピラ症 8 例の人患 者が発生した際に, 国立感染症研究所感染症情報センター (当時の名称), 同 FETP (実地疫学専門家養成コース), 同細菌第一部が宮崎県に協力して調査が行われた ${ }^{14)}$ 。その 際, 農作業中の水道 - 井戸以外の水や土への創傷部の接触 などが感染リスクとして関連づけられ，獣医師会の協力を 得てレプトスピラ症に感染したイヌの全数把握を行うこと で, ヒトー動物と広い範囲での正確な実態を把握し, 早期 発見・早期治療を行い蔓延防止に努めることが出来る, と の提言がなされた。

米国では, 野外で活動する愛玩動物や猟犬などのイヌは, 污染された水を飲むことなどによって，ヒトと同様に自然 環境においてレプトスピラに曝露し, 感染を受けるリスク が高いことが知られている ${ }^{15)}$ 。図 2 に，2005〜2015 年（暫 定）の, 我が国における, 第 4 類のヒト感染症のレプトス ピラ症と ${ }^{16)}$, 家畜伝染病予防法に届出られたイヌのレプト

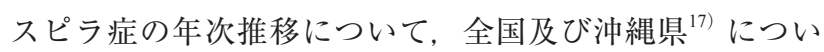
て比較した（図 2)。その結果, 県レベルのヒトとイヌの レプトスピラ症との関連は必ずしもはっきりしないもの の, 2008 年や, 2013-2014 年の報告数が多い年については, 何らかの関連があるようにも見受けられる。今後, それぞ れのサーベイランスの質を高めることで, これらの情報の 
精度が増し, 人獣共通感染症としてのレプトスピラ症を総 合的に分析・評価し, 次の, より良い対策につなげること が出来るかもしれない, と考えられた。

\section{おわりに}

獣医師が届け出を求められるサーベイランスとして, 感 染症法に基づくものと, 家畜伝染病予防法に基づくものと があり, それぞれの対象疾患の中には人獣共通感染症が含 まれている。人獣共通感染症へのより効率的かつアクティ ブな対応は, ヒトの衛生, 家畜の衛生, 環境の衛生の関係 者が連携して対策に取り組むべきであるといった“One Health”の理念にも叶うものである ${ }^{18)}$ 。前述のように, サー ベイランスへの届出を促進させるためにはいくつかの要素 があり, デー夕提供者の動機づけ, 容易な収集方法, 明確 な定義などは重要であり, それぞれの要素が関連すること で, サーベイランスの向上につながっていくはずである。 デー夕提供者の動機づけについては獣医系の関係団体から の周知促進についても期待するとともに, 容易な収集方法 については, サーベイランスの体制をどのように組むかと いう点で, 国レベルの役割も大きいと思われる。

また,レプトスピラ症を特に挙げてみたことについては, 愛玩動物由来感染症が, 家族としてのペットの位置づけが 変わってくる中で, 国内でも今後は注意を払うべき重要な 人獣共通感染症の対象の一つとなると考えられたからであ る。愛玩動物の健康を守ること, 飼育者のリスクを少なく することは, 地域の医療や福祉, 公衆衛生の向上にも結び 付くものであると考える。今後も, 人獣共通感染症対策へ の重要なポイントとして, 獣医師のサーベイランスへのよ り積極的な参加をお願いしたい。

\section{謝 辞}

データの収集・整理に協力してくださった，辻朋子さん (国立感染症研究所感染症疫学センタースタッフ)に心よ り感謝申し上げます。

\section{参考文献}

1）厚生労働省ホームページ：感染症法に基づく獣医師が 届出を行う感染症と動物について. Available at : http:// www.mhlw.go.jp/stf/seisakunitsuite/bunya/kenkou_iryou/ kenkou/kekkaku-kansenshou/kekkaku-kansenshou11/02. html

2) Gray GC et al. : Influenza A(H1N1)pdm09 virus among healthy show pigs, United States. Emerg Infect Dis [serial on the Internet]. $2012 \mathrm{Sep}$ [date cited]. Available at : http:// dx.doi.org/10.3201/eid1809.120431

3）感染症の予防及び感染症の患者に対する医療に関する
法律（平成十年十月二日法律第百十四号）（最終改正 : 平成二六年一一月二一日法律第一一五号). Available at : http://law.e-gov.go.jp/htmldata/H10/H10HO114.html

4）7）中村好一：サーベイランスと疾病登録. 基礎から 学ぶ楽しい疫学第 2 版, 医学書院. 東京, 2006.

5）厚生労働省 : 感染症発生動向調査について. Available at : http://www.mhlw.go.jp/stf/seisakunitsuite/bunya/ 0000115283.html

6）厚生労働省 : 感染症法に基づく獣医師が届出を行う感 染症と動物について. Available at : http://www.mhlw. go.jp/stf/seisakunitsuite/bunya/kenkou_iryou/kenkou/ kekkaku-kansenshou/kekkaku-kansenshou11/02.html

7）国立感染症研究所感染症情報センター（担当：佐藤 弘, 多田有希）: 感染症法に基づき獣医師より届け出 られた「細菌性赤痢のサル」の報告状況. IASR, 30, 317-319, 2009. Available at : http://idsc.nih.go.jp/iasr/30/ 358/dj3583.html

8）国立感染症研究所ホームページ：年別報告数一覧（全 数把握 [動物]). 獣医師が届出を行う感染症と対象動 物（2015 年 10 月 25 日現在報告数）. Available at： http://www.nih.go.jp/niid/ja/survei/2085-idwr/ydata/5670animal-ja2014.html

9）棚林 清 : 厚生労働省ホームページ：サル（人以外の 霊長類）の細菌性赤痢. Available at : http://www.mhlw. go.jp/bunya/kenkou/kekkaku-kansenshou11/pdf/02-04.pdf

10）厚生労働省：感染症法に基づく医師及び獣医師の届出 について.43レプトスピラ症. Available at: http:// www.mhlw.go.jp/bunya/kenkou/kekkaku-kansenshou11/ 01-04-40.html

11）国立感染症研究所ホームページ：レプトスピラ症 2007 年 1 月〜2016 年 4 月, IASR, 37, 103-105, 2016. Available at : http://www.nih.go.jp/niid/ja/leptospirosis-m/ leptospirosis-iasttpc/6518-436t.html

12）日本獣医師会 : 届出に関する Q\&A. Available at : http: //nichiju.lin.gr.jp/ekigaku/todoke/06.html

13）農林水産省ホームページ：監視伝染病の発生状況. 監 視伝染病発生年報 (平成 10 年分〜平成 27 年分). Available at : http://www.maff.go.jp/j/syouan/douei/kansi_ densen/kansi_densen.html

14）塩山陽子ら：宮崎県におけるレプトスピラ症の発生と その対応. IASR, 29, 12-13, 2008. Available at : http:// idsc.nih.go.jp/iasr/29/335/dj3355.html

15) American Veterinary Medical Foundation : Leptospirosis. Available at : https://www.avma.org/public/PetCare/Pages/ Leptospirosis.aspx

16）国立感染症研究所ホームページ：感染症発生動向調査 
年別一覧表一2014一. Available at : http://www.nih.go. jp/niid/ja/survei/2085-idwr/ydata/6043-ydata2014.html

17）沖縄県記者発表：レプトスピラ症の集団発生事例につ いて (平成 28 年 9 月 28 日). Available at : http://www. pref.okinawa.jp/site/hoken/eiken/kikaku/kansenjouhou/ documents/160928lepto.pdf

18）厚生労働省 : One Healthの取り組み. Available at : http: //www.mhlw.go.jp/stf/seisakunitsuite/bunya/0000113218. html 